\author{
Research Article
}

\title{
Corporate Reputation and Bankruptcy Risk
}

\author{
Alan Diógenes Góis ${ }^{1}$ (in memoriam) \\ Márcia Martins Mendes De Luca ${ }^{2}$ \\ Gerlando Augusto Sampaio Franco de Lima ${ }^{3}$ \\ Jislene Trindade Medeiros ${ }^{2}$ \\ ${ }^{1}$ Universidade de São Paulo, São Paulo, SP, Brazil \\ ${ }^{2}$ Universidade Federal do Ceará, Fortaleza, CE, Brazil \\ ${ }^{3}$ University of Illinois at Urbana-Champaign, Illinois, USA
}

Received 19 December 2018. This paper was with the authors for two revisions. Accepted 6 April 2020. First published online 5 May 2020.

Carlos Eduardo Facin Lavarda was the associate editor for this article.

Editor-in-chief: Carlo Gabriel Porto Bellini

Editorial assistant: Luciane Kato Kiwara 


\section{Abstract}

In view of the influence of corporate reputation on investors' choices and risk concerns, the purpose of this study was to explore the relationship between corporate reputation and bankruptcy risk in public firms. The investigation is a contribution to the burgeoning literature on corporate reputation associated with accounting, despite reputation being classified as an intangible asset capable of generating competitive advantage. Our sample included 4,578 observations (441 firms) covering the period 2005-2016. The overall score on the World's Most Admired Companies ranking was used as a proxy for reputation. Bankruptcy risk was quantified by Altman Z-scores (Zang, 2012) and accounting information for each year in the period was retrieved from the database Compustat Global. Our results reveal that corporate reputation has a negative influence on bankruptcy risk, reiterating the importance of risk management. When firms attract and strive to secure the favor of stakeholders, they increase risk for the same reason. However, this effect is counterbalanced by good reputation. Thus, corporate reputation is a valuable strategic resource with which managers can boost confidence among investors, increase the firm's credit worthiness and perpetuate the organization on the market. Furthermore, these results expand the literature on corporate reputation and risk of bankruptcy, and show signs that companies with high reputation have lower risk of bankruptcy and tend to honor their debts.

Keywords: corporate reputation; bankruptcy risk; Altman Z-score.

JEL code: F230 


\section{Introduction}

Relentless competition, market globalization, and an ever-increasing supply of products and services induce firms to strive to gain an edge over their peers (Castro \& López, 2006; Gotsi \& Wilson, 2001). To do so, firms employ strategic resources, such as assets, skills, organizational processes, attributes, and information. Based on the Resource-Based View, these resources must be valuable, rare, inimitable, and non-substitutable to generate a competitive advantage (Barney, 1991).

Corporate reputation is an important and valuable strategic resource which can provide a competitive advantage and help attain and sustain superior financial performance (Inglis, Morley, \& Sammut, 2006; Melo \& Garrido-Morgado, 2012; Roberts \& Dowling, 2002). It may be seen as an aggregation of stakeholder perceptions about the firm, developed over time, representing an important intangible asset (Barnett, Jermier, \& Lafferty, 2006; Roberts \& Dowling, 2002).

According to Feldman, Bahamonde, and Bellido (2014), corporate credibility - one of the benefits of a high reputation - attracts more and more investors as the firm's market value increases and risk decreases. Understanding the relationship between corporate reputation and risk is of utmost importance in view of the role reputation plays in strategic management (Henkel, 2009), with repercussions on performance and risk (Delgado-García, Quevedo-Puente, \& Díez-Esteban, 2013).

Investment in reputation helps reduce information asymmetry between managers, the market, and investors by providing stakeholders with information not contained in financial reports ( $\mathrm{Li}$, 2010) and thereby increasing confidence in company actions, policies, and strategies. As pointed out by Delgado-García, Quevedo-Puente and Díez-Esteban (2013), because corporate reputation serves as an information signal of potential future firm behavior, its influence on corporate risk may be stronger in firms about which stakeholders have less complete information.

Risk may be seen as the interpretation of the level of uncertainty associated with a given event for which a return is expected (Eiser et al., 2012). Several types of risk are described in the literature: fluctuations in economic variables (stock prices, exchange rates, interest rates, commodity prices), risk of loss due to inadequate systems and controls, management failure and fraud, risk of non-compliance and/or default on contracts, and risk of failing legal support (Eiser et al., 2012; Linsley \& Shrives, 2006; Rodríguez-Moreno \& Peña, 2013). In Hull (2015), corporate risks are segregated into four groups: market risk, operational risk, credit risk, and legal risk. The present study focuses on credit risk, which estimates the likelihood of bankruptcy.

Credit risk is the risk of default on payment or debtor's non-compliance, potentially leading to bankruptcy. In other words, credit risk indicates a firm's propensity to fail, mostly due to inefficient resource management, based on accounting reports indicating corporate insolvency

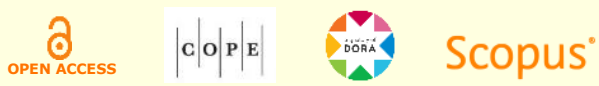


(Altman, 1968). In this context, reputation can ensure market prominence, attract new talent and customers, and provide better bargaining power with suppliers (Feldman, Bahamonde, \& Bellido, 2014), giving firms a competitive advantage and making them less likely to fail (Casado, Yanez, \& Peláez, 2017). Firms with good reputation tend to be longevous, less susceptible to bankruptcy, and more resilient in times of crisis (Fombrun, Gardberg, \& Barnett, 2000).

In view of the influence of corporate reputation on investors' choices and risk concerns (Cole, 2012), in this study we explore the relationship between corporate reputation and bankruptcy risk.

Our sample included 441 firms listed at least once on the Fortune ranking of the World's Most Admired Companies (WMAC) in the period 2005-2016. We used the overall score on the WMAC ranking as a proxy for reputation and quantified bankruptcy risk in Altman Z-scores (Zang, 2012). Accounting information for each year in the period was retrieved from the database Compustat Global.

Our study provides subsidies for informed decision making about future investments, whether conservative or hazardous, based on an understanding of the relationship between corporate reputation and bankruptcy risk. The results show that firms with high reputation have lower risk, suggesting that credibility associated with corporate reputation has a favorable influence on investor decision making. Thus, reputation may be considered complementary to accounting reports for the sake of investment analysis.

The present investigation is a contribution to the burgeoning literature on corporate reputation associated with accounting, despite reputation being classified as an intangible asset capable of generating competitive advantage. The study also contributes to the literature on bankruptcy risk by providing empirical evidence for how bankruptcy risk may be affected not only by corporate reputation, but also by macroeconomic factors, regulatory quality, and the rule of law in each country.

\section{Theoretical Framework}

The topic of corporate reputation has been explored by scholars of many different fields, including economics, strategy, marketing, organization theory, accounting, and sociology (Fombrun \& Van Riel, 1997). However, the concept has still not been defined in universally accepted terms (Chun, 2005).

Barnett, Jermier and Lafferty (2006) identified three major clusters of meaning in the concept of corporate reputation: awareness, assessment, and asset. As for the first, reputation may be defined as an aggregation of perceptions of the organization among stakeholders and other observers, without making judgments. As for the second, reputation is the result of a judgment, estimate, evaluation, or gauge. Being judgmental in nature, it is akin to an opinion or belief and includes the attractiveness of the firm and the regard in which it is held. The third cluster refers to reputation as an intangible asset of real value. The authors point out that despite some overlap, the clusters are relatively distinct. Awareness does not imply an assessment, and

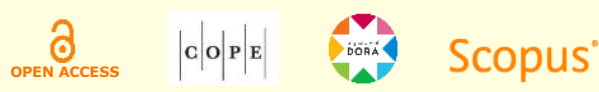


assessment does not imply transformation into an asset. In the present study, reputation is considered an intangible asset.

Berens and Van Riel (2004) classified studies on reputation into three categories: social expectations, corporate personality, and trust. The first category includes studies associating reputation with social expectations regarding organizational behavior. The second category covers reputation as a set of personality traits attributed to companies. The third category includes studies associating reputation with trust, that is, the perception of honesty and trust in the firm. The present study may be classified in the third category.

In other words, corporate reputation may be seen as a strategic (thus intangible) asset with enough business value to confer a competitive advantage on the organization and attain superior performance, as long as the market trusts the firm's strategies (Fombrun \& Van Riel, 1997). From the perspective of Recourse-Based View (RBV), in order to attain and sustain this level of performance, strategic assets must be valuable, rare, inimitable, and non-substitutable (Barney, 1991).

Other benefits of a good reputation associated with superior performance include willingness on part of consumers to pay more for the company's products and services, greater attractiveness for potential partners, and lower risk in the eyes of investors (Walker, 2010). Feldman et al. (2014) also point out that organizational credibility tends to attract more investors by increasing market value and reducing risk.

According to Fombrun and Shanley (1990), investors prefer firms with high performance and low risk due to their propitious trajectory and perspectives. Optimistic projections motivate investors to acquire stock, and this in turn increases the firm's market value and shows the firm is capable of fulfilling its economic and social goals (Cole, 2012).

Thus, corporate reputation serves as an indication of potential future behaviors and plays a role in risk assessment. Indeed, the negative impact of bankruptcy risk is greater when stakeholders are not given access to complete company information (Delgado-García et al., 2013). Cole (2012) reiterates that investors' choices may depend on whether the company's reputation is high enough to allay their concerns about risks.

Herremans, Akathaporn, and McInnes (1993) investigated corporate reputation as a measure of social responsibility in relation to financial performance in the period 1982-1987. The Fortune 500 ranking, which takes social responsibility into account, was used as a proxy for reputation. Operating margin, net margin, return on assets (ROA), and return on equity (ROE) were used as performance indicators. In addition, the authors evaluated total risk and systematic risk. A strong correlation was found between good reputation (with emphasis on social responsibility) and high returns, and between good reputation and low total risk.

Hammond and Slocum (1996) published a similar study involving 149 firms from the Fortune (1993) ranking of America's Most Admired Companies for the years 1981 and 1986. They

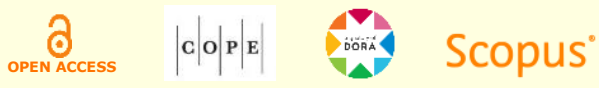


expressed reputation as attributes of social responsibility according to Fortune criteria and used market-based risk and return variables and accounting measures of return as performance indicators. The results for 1981 indicated that firms with low risk (expressed as $\beta$ coefficient) and high ROE enjoyed the highest reputation, associated with an image of high social responsibility.

To interpret these studies, the concept of risk and the types of risk employed in the analysis must be understood. According to Gupta (2014), no universally accepted definition exists. However, Hull (2015) sees risk as the interpretation of the level of uncertainty associated with an event and classifies it into market risk, operational risk, credit risk, and legal risk. Our study analyzes bankruptcy risk as a type of credit risk. Like all risks, bankruptcy risk affects corporate reputation, hence perpetuation on the market - a major goal of all firms. Continuity is also one of the principles of accounting. Thus, it is important to understand how reputation relates to this type of risk.

Credit risk may be said to arise when individuals or firms acquire goods or services in return for a promise of future payment (Gupta, 2014). Thus, credit risk is the probability that one of the parties will default on or delay payment, potentially triggering a process of bankruptcy. The Altman Z-score, one of the metrics used to quantify credit/bankruptcy risk, was developed in 1981 by Edward Altman and James La Fleur as a model of discriminant analysis employing traditional financial indicators (Gupta, 2014): the working capital/total assets ratio, the retained earnings/total assets ratio, the earnings before interest and taxes/total assets ratio, the market value of equity/book value of total liabilities ratio, and the sales/total assets ratio (Hull, 2015).

The higher the Altman Z-score, the better the firm's financial health and the less likely a scenario of bankruptcy. With Altman Z-scores over 3, firms may be expected to honor their debts and remain in business (Gupta, 2014; Hull, 2015). A score between 3 and 2.7 should alert investors to possible difficulties, while scores between 2.7 and 1.8 indicate a palpable risk of insolvency. Firms with scores below 1.8 are very likely to go bankrupt (Gupta, 2014; Hull, 2015).

The few studies correlating corporate reputation and risk have mostly focused on market risk (Casado et al., 2017), while bankruptcy risk has almost exclusively been explored from the theoretical perspective. In fact, most authors use risk as a control variable.

Fombrun and Shanley (1990) believe firms compete for reputation in a market characterized by incomplete information. The authors investigated the impact of corporate reputation in a sample of 292 British firms from the 1985 Fortune list. Reputation (dependent variable) was quantified using an index derived from the Fortune ranking. The independent variables included size, financial performance, risk level, institutional ownership, media exposure, differentiation, and diversification. The authors found the variables "financial performance" (return on capital invested and market-to-book ratio), "institutional ownership," and "size" to have a positive effect on corporate reputation, while the variable "risk" (based on accounting) had a negative effect.

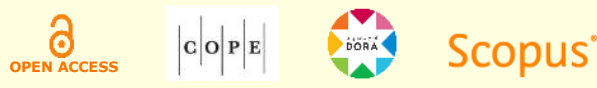


Brammer, Millington and Pavelin (2009) investigated the relationship between corporate reputation and the presence of women on the board of directors in a sample of 199 British firms. Reputation was quantified based on the ranking of the Most Admired Companies in Great Britain published in the 2002 edition of Management Today. The control variables included the $\beta$ coefficient as a measure of market risk. Based on the $\beta$ coefficient, market risk had a negative effect on corporate reputation.

Financial performance depends not only on high returns but also on low risk. By reducing risk, good corporate reputation is therefore likely to improve performance. According to DelgadoGarcía et al. (2013), little has been published on the relationship between risk and corporate reputation, despite the importance of the subject to strategic management (Henkel, 2009).

Delgado-García et al. (2013) evaluated the impact of corporate reputation on systematic risk, non-systematic risk, and total risk in a sample of 96 Spanish public firms covering the period 2001-2007. The authors expressed systematic risk in CAPM-generated $\beta$ coefficients, calculated total risk derived from the model as variance of returns, represented non-systematic risk by the standard deviation of the error term of the model, and used the participation and score of the company on the Merco ranking as a proxy for reputation. When a dummy variable was used for reputation, non-systematic risk and total risk were negatively correlated with reputation, while systematic risk was positively impacted by reputation. When reputation was quantified by scores on the Merco ranking, the authors observed a negative correlation between non-systematic risk and reputation. No significant correlations were found for systematic risk or total risk.

Corporate reputation can be measured with several different methods (Gotsi \& Wilson, 2001). According to Wartick (2002), most approaches to the measurement of corporate reputation are focused on stakeholder perception and are used to compare firms, especially with regard to financial performance. Indeed, as pointed out by Chun (2005), such approaches are often criticized for being excessively concerned with financial performance.

Moreover, the Reputation Institute (http://www.reputationinstitute.com), a major international reference for the measurement of corporate reputation conducting research on all continents, has developed a methodology (RepTrak) which captures stakeholders' perceptions about organizations by measuring the level of trust, esteem, admiration, and respect in each one of seven key dimensions (leadership, performance, products, innovation, workplace, governance, and citizenship).

In this study, we used the most widely known corporate reputation metric: the Fortune ranking of the World's Most Admired Companies (Fombrun, 2007).

Based on these considerations and on the literature (Brammer, Millington, \& Pavelin, 2009; Casado et al., 2017; Delgado-García et al., 2013; Fombrun \& Shanley, 1990; Hammond \& Slocum, 1996; Krueger \& Wrolstad, 2016), we formulated the following hypothesis:

$H_{1}$ : Corporate reputation is negatively correlated with bankruptcy risk.

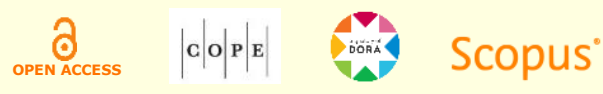


The hypothesis is based on the assumption that corporate reputation is correlated with bankruptcy risk. Good reputation generates benefits, such as attracting and retaining talents, attracting investors, outperforming the competition, capturing more resources, and boosting trust. Thus, reputation tends to legitimize the firm on the market and confer longevity, making bankruptcy an unlikely event (Casado et al., 2017; Flanagan \& O'Shaughnessy, 2005; Musteen, Datta, \& Kemmerer, 2010).

\section{Methodology}

The sample population consisted of firms listed at least once on the Fortune ranking of the World's Most Admired Companies (WMAC) in the period 2005-2016. The ranking is built with the scores of the 500 largest firms in the world and the 1,000 largest US firms based on revenue and a rating by executives, directors, and financial analysts using nine criteria, ranging from market value and product and management quality to social responsibility and ability to attract talents: innovation, personnel management, use of corporate assets, social responsibility, management quality, financial robustness, long-term investment value, product and service quality, and global competitiveness.

The desired information was available for only 441 firms (4,578 observations). Table 1 shows the observations of company bankruptcy risk, represented by ALTM, according to country.

Table 1

\section{Sample by country}

\begin{tabular}{lccc}
\hline COUNTRY & & ALTM & Cumulative \\
\hline CANADA & Frequency & Percent & 0.87 \\
GERMANY & 40 & 0.87 & 1.05 \\
FINLAND & 8 & 0.17 & 1.07 \\
IRELAND & 1 & 0.02 & 2.42 \\
JAPAN & 62 & 1.35 & 2.56 \\
SINGAPORE & 6 & 0.13 & 2.75 \\
SPAIN & 9 & 0.20 & 2.80 \\
SWEDEN & 2 & 0.04 & 2.82 \\
SWITZERLAND & 1 & 0.02 & 2.95 \\
UNITED KINGDOM & 6 & 0.13 & 3.60 \\
UNITED STATES & 30 & 0.66 & 100 \\
\hline Total & 4.413 & 96.40 & 100 \\
\hline
\end{tabular}

Note. ALTM = bankruptcy risk. 
Note that, although the study was based on a global ranking, the sample consisted mostly of US firms. International firms were defined as firms traded on US stock markets (NYSE, NASDAQ, etc.). This fact arises due to the criteria of the World's Most Admired Companies (WMAC) ranking, in which it recovers $25 \%$ for American companies.

In order to evaluate the relationship between corporate reputation and bankruptcy risk (the main objective of the study), we submitted our findings to panel data multiple linear regressions with fixed effects and robust errors:

$$
\begin{aligned}
& \mathrm{ALTM}_{\mathrm{it}}=\beta_{0}+\beta_{1} \mathrm{REP}_{\mathrm{it}-1}+\beta_{2} \mathrm{ROA}_{\mathrm{it}}+\beta_{3} \mathrm{LEV}_{\mathrm{it}}+\beta_{4} \mathrm{INT}_{\mathrm{it}}+\beta_{5} \mathrm{EPS}_{\mathrm{it}}+\beta_{6} \mathrm{SIZE}_{\mathrm{it}}+ \\
& \beta_{7} \text { IFRS }_{\text {it }} \beta_{8} \mathrm{AUD}_{\text {it }}+\beta_{9} \mathrm{CRIS}_{\text {it }} \beta_{10} \mathrm{GDP}_{\text {it }}+\beta_{11} \mathrm{RL}_{\mathrm{it}}+\beta_{12} \mathrm{RQ}_{\mathrm{it}}+\varepsilon_{\text {it }}
\end{aligned}
$$

Although the Z-score model was developed in the 1960s and is only one among many bankruptcy prediction models, it is still widely used in both research and operations as primary or ancillary tool for the analysis and prediction of financial distress and bankruptcy (Altman, Iwanicz-Drozdowska, Laitinen, \& Suvas, 2017). Tinoco and Wilson (2013) used the Z-score as a reference against which to measure the performance of a model developed for UK firms, and the Altman Z-score achieved $81 \%$ accuracy in the identification of firms in financial difficulties. Moreover, when the model proposed by Altman (1968) was used by Chava and Jarrow (2004) to detect bankruptcy in a large sample of insolvent US firms between 1991 and 1999, 63.2\% of the actual bankruptcies were correctly predicted.

Based on the literature, corporate reputation was expected to be negatively associated with bankruptcy risk. In other words, the greater the corporate reputation (higher REP value), the smaller the bankruptcy risk (higher ALTM value).

Table 2 shows the dependent, independent, and control variables used in the study.

Table 2

\begin{tabular}{|c|c|c|c|}
\hline Variable & & Metric & Operationalization \\
\hline & & & $0.3^{*}(\mathrm{~N} I / T A)+(\mathrm{S} / \mathrm{TA})+1.4^{*}(R E / T A)+1.2^{*}(\mathrm{WC} / \mathrm{TA})+0.6^{*}(\mathrm{MV} / \mathrm{TL})$ \\
\hline Dependent & ALTM & Bankruptcy risk & $\begin{array}{l}\mathrm{NI}=\text { net income; } \mathrm{TA}=\text { total assets; } \mathrm{S}=\text { sales } ; \mathrm{RE}=\text { retained earnings; } \\
\mathrm{WC}=\text { working capital; } \mathrm{MV}=\text { market value; } \mathrm{TL}=\text { total liabilities }\end{array}$ \\
\hline Independent & REP & Corporate reputation & Overall WMAC score \\
\hline \multirow{6}{*}{ Controls } & ROA & Return on assets & Net income/total assets \\
\hline & LEV & Leverage & Total debt/total assets \\
\hline & INT & Intangibility & Market value/shareholders' equity \\
\hline & EPS & Earnings per share & Natural logarithm of earnings per share excluding extraordinary items \\
\hline & SIZE & Company size & Natural logarithm of total assets \\
\hline & IFRS & $\begin{array}{l}\text { International Financial } \\
\text { Reporting Standards }\end{array}$ & $\begin{array}{l}\text { Dummy variable in which } 1 \text { represents years following the adoption of } \\
\text { IFRS; } 0 \text { otherwise }\end{array}$ \\
\hline
\end{tabular}

Measurement and description of dependent, independent, and control variables

Continues

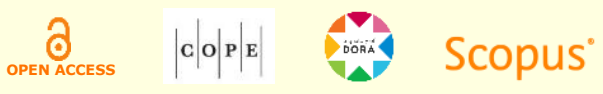


Table 2 (continued)

\begin{tabular}{|c|c|c|c|}
\hline Variable & & Metric & Operationalization \\
\hline \multirow{5}{*}{ Controls } & AUD & Audit quality & $\begin{array}{l}\text { Dummy variable in which } 1 \text { represents firm audited by one of the Big } \\
\text { Four; } 0 \text { otherwise }\end{array}$ \\
\hline & CRIS & Financial crisis & Dummy variable in which 1 represents the year 2008; 0 otherwise \\
\hline & GDP & $\begin{array}{l}\text { Gross Domestic } \\
\text { Product }\end{array}$ & Annual variation in GDP \\
\hline & $\mathrm{RL}$ & Rule of law & $\begin{array}{l}\text { Rule of law captures perceptions of the extent to which agents have } \\
\text { confidence in and abide by the rules of society, and in particular the } \\
\text { quality of contract enforcement, property rights, the police, and the } \\
\text { courts, as well as the likelihood of crime and violence }\end{array}$ \\
\hline & $\mathrm{RQ}$ & Regulatory quality & $\begin{array}{l}\text { Regulatory quality captures perceptions of the ability of the government } \\
\text { to formulate and implement sound policies and regulations that permit } \\
\text { and promote private sector development }\end{array}$ \\
\hline
\end{tabular}

The choice of study variables was based on a review of the literature on corporate reputation and risk (Ahn \& Choi, 2009; Borghesi, Houston, \& Naranjo, 2014; Casado et al., 2017; Hasseldine, Salama, \& Toms, 2005; Himme \& Fischer, 2014; Musteen, Rhyne, \& Zheng, 2013; Toms, 2002). This included the following control variables: return on assets (Henkel, 2009), leverage (Beaver, 1966; Jiraporn, Jiraporn, Boeprasert, \& Chang, 2014), intangibility (Jiraporn et al., 2014), earnings per share (Horrigan, 1966), company size (Borghesi et al., 2014), IFRS (Chan, Hsu, \& Lee, 2013), audity quality (Hammond \& Slocum, 1996), financial crisis (Jones, Jones, \& Little, 2000), annual variation in GDP (Butler \& Fauver, 2006; Tinoco \& Wilson, 2013), rule of law (Butler \& Fauver, 2006), and regulatory quality (Butler \& Fauver, 2006; Godlewski, 2006).

The sample consisted of firms appearing at least once on the WMAC ranking between 2005 and 2016. Based on the assumption that absence from the ranking is an indication of low reputation, we assigned the value 0 (zero) to the variable REP in the years in which a firm was not listed. However, to avoid sampling bias, we performed a second analysis considering only REP values $\neq 0$.

Our analysis starts with a descriptive statistic of ALTM and REP and a comparison between the groups with regard to these two variables using parametric tests ( $t$ tests) and non-parametric tests (Mann-Whitney). To determine whether inclusion in the Fortune ranking of the World's Most Admired Companies had an impact on ALTM, we segregated the sample into two groups: observations covering the years when the sampled firms were not listed in the ranking, and observations covering the years when the sampled firms were listed. To test the association between bankruptcy risk and reputation, we also segregated the sample into firms with high vs. low bankruptcy risk (ALTM $\leq 3$ vs. >3). In addition, we analyzed the correlations between all the study variables and, testing the hypothesis, performed panel data regressions with fixed effects to evaluate the effect of the firm over time. 


\section{Analysis of Results and Discussion}

Using Student's $t$ test and the Mann-Whitney test, we initially verified whether the bankruptcy risk of the sampled firms during the study period (2005-2016) was significantly associated with inclusion in the Fortune ranking of the World's Most Admired Companies. Table 3 shows the results of the analysis.

Table 3

\section{Group descriptives}

\begin{tabular}{lccccc}
\hline & ALTM & Student's $t$ & $\begin{array}{c}\text { Mann-Whitney test } \\
\text { (p-value) }\end{array}$ & $(p$-value $)$ \\
\cline { 2 - 4 } Mean & Total & 0 & 4.24 & 4.27 & \\
Standard deviation & 4.26 & 0.662 & 0.631 & & \\
Minimum & 3.40 & 0.003 & 0.003 & 0.797 & 0.552 \\
Median & 0.003 & 2.79 & 2.86 & \\
Maximum & 2.83 & 6.80 & 6.56 & \\
$\mathrm{~N}$ & 6.80 & 2187 & 2391 & \\
\hline
\end{tabular}

Note. Source: the authors. ALTM = Altman Z-score according to Zang (2012); 0 = observations of firms during years of absence from the Fortune ranking of the World's Most Admired Companies (WMAC); 1 = observations of firms during years of inclusion in the Fortune ranking of the World's Most Admired Companies (WMAC).

The results of Student's $t$ test and the Mann-Whitney test (Table 3) show that, for the period covered by the study, the risk of bankruptcy was not significantly impacted by inclusion in the Fortune ranking of the World's Most Admired Companies. In other words, the higher corporate reputation presumably afforded by inclusion in the ranking did not significantly lower the bankruptcy risk.

Furthermore, the high mean Altman Z-score of the sampled firms (4.26) suggests that highly reputed firms are not at risk of bankruptcy (Gupta, 2014; Hull, 2015). The low overall bankruptcy risk in our sample may in part be justified by the large size of the firms listed in the Fortune ranking. In fact, a comparison of the two groups shows that the Altman Z-score was statistically similar whether the firm was listed in the ranking or not.

To determine whether firms with low bankruptcy risk differed from firms in financial distress with regard to reputation, we submitted the data to Student's $t$ test and the Mann-Whitney test. The results are shown in Table 4. 
Table 4

\section{Group descriptives}

\begin{tabular}{|c|c|c|c|c|c|}
\hline & \multicolumn{3}{|c|}{ REP } & \multirow{2}{*}{$\begin{array}{l}\text { Student's t } \\
\text { (p-value) }\end{array}$} & \multirow{2}{*}{$\begin{array}{c}\text { Mann-Whitney test } \\
(p \text {-value })\end{array}$} \\
\hline & Total & 0 & 1 & & \\
\hline Mean & 3.30 & 3.23 & 3.42 & \multirow{6}{*}{0.004} & \multirow{6}{*}{0.000} \\
\hline Standard Deviation & 3.25 & 3.18 & 3.32 & & \\
\hline Minimum & 0 & 0 & 0 & & \\
\hline Median & 4.69 & 4.44 & 4.98 & & \\
\hline Maximum & 8.80 & 8.40 & 8.80 & & \\
\hline$N$ & 4578 & 2437 & 2141 & & \\
\hline
\end{tabular}

Note. Source: the authors. REP = lagged overall WMAC score; 0 = firms with Altman Z-score $\leq 3 ; 1=$ firms with Altman Z-score $>3$.

As illustrated in Table 4, firms at risk of financial difficulties and bankruptcy (Altman Z-score $\leq$ 3) were less well reputed than firms with low risk of bankruptcy due to their ability to pay debts. Thus, our findings suggest different levels of reputation in firms with low risk of bankruptcy vs. firms at high risk of insolvency.

The mean REP was low in the sample (Table 4), but, as explained in the previous section, REP was assigned the value 0 in years of absence from the Fortune ranking. In general, sampled firms with REP $=0$ did not have their reputation quantified with WMAC criteria (innovation, personnel management, use of corporate assets, social responsibility, management quality, financial robustness, long-term investment value, product and service quality, and global competitiveness).

Before proceeding with the regression analysis, we submitted the variables to Pearson correlation analysis. Table 5 shows the coefficient of each correlation.

Table 5

Pearson correlations

\begin{tabular}{|c|c|c|c|c|c|c|c|c|c|c|c|c|c|}
\hline & ALTM & REP & ROA & LEV & INT & EPS & SIZE & IFRS & AUD & CRIS & GDP & $\mathbf{R L}$ & $\mathbf{R Q}$ \\
\hline ALTM & 1 & & & & & & & & & & & & \\
\hline REP & $\underset{* \star}{0.031}$ & 1 & & & & & & & & & & & \\
\hline ROA & $\underset{* * \star}{0.511}$ & 0.013 & 1 & & & & & & & & & & \\
\hline LEV & $\underset{\star}{-0.608}$ & $\begin{array}{c}-0.025 \\
*\end{array}$ & $\underset{* \star \star}{-0.216}$ & 1 & & & & & & & & & \\
\hline INT & $\underset{* * \star}{0.353}$ & 0.023 & $\underset{* * \star}{0.255}$ & $\underset{* \star \star}{0.119}$ & 1 & & & & & & & & \\
\hline EPS & $\underset{* * \star}{0.200}$ & 0.008 & $\underset{* * *}{0.138}$ & $\underset{* * *}{-0.118}$ & $\underset{\star \star \star \star}{0.094}$ & 1 & & & & & & & \\
\hline
\end{tabular}

Continues 
Table 5 (continued)

\begin{tabular}{|c|c|c|c|c|c|c|c|c|c|c|c|c|c|}
\hline & ALTM & REP & ROA & LEV & INT & EPS & SIZE & IFRS & AUD & CRIS & GDP & $\mathbf{R L}$ & $\mathbf{R Q}$ \\
\hline SIZE & -0.440 & $\begin{array}{c}0.002 \\
*\end{array}$ & -0.064 & $\underset{* * *}{0.378}$ & $\underset{* \star \star}{-0.259}$ & $\underset{\star \star \star \star *}{-0.236}$ & 1 & & & & & & \\
\hline IFRS & $\underset{* * \star}{0.2646}$ & $\begin{array}{c}- \\
0.046 \\
5 \\
\star \star\end{array}$ & $\underset{* *}{-}$ & $\underset{* \star \star}{0.1381}$ & $\underset{\substack{* * * \\
0.1444}}{-}$ & 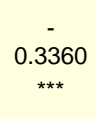 & $\begin{array}{c}0.3745 \\
* * *\end{array}$ & 1 & & & & & \\
\hline AUD & $\underset{* \star \star}{0.053}$ & 0.005 & $\begin{array}{c}0.219 \\
* \star *\end{array}$ & $\underset{* \star 13}{0.133}$ & 0.015 & $\begin{array}{c}0.057 \\
\star \star \star \star\end{array}$ & $\begin{array}{c}0.283 \\
* * *\end{array}$ & $\underset{* \star \star}{0 .}$ & 1 & & & & \\
\hline CRIS & $\underset{* \star * \star}{-0.041}$ & -0.001 & 0.007 & -0.003 & $\underset{* * *}{-0.098}$ & -0.003 & -0.019 & $\underset{* \star * \star}{0.0001}$ & 0.001 & 1 & & & \\
\hline GDP & $\begin{array}{c}-0.063 \\
* * *\end{array}$ & -0.006 & $\underset{* * *}{0.042}$ & -0.008 & $\underset{* \star \star}{0.110}$ & $\underset{* *}{0.031}$ & $\underset{* *}{-0.036}$ & $\underset{* \star}{0.0408}$ & 0.003 & $\underset{* \star \star}{-0.318}$ & 1 & & \\
\hline $\mathbf{R L}$ & -0.023 & 0.017 & $\begin{array}{c}0.027 \\
*\end{array}$ & $\underset{* * \star}{-0.050}$ & $\begin{array}{c}0.060 \\
* * *\end{array}$ & $\underset{* *}{0.028}$ & $\begin{array}{c}-0.117 \\
* \star *\end{array}$ & $\begin{array}{c}0.1494 \\
\star \star \star\end{array}$ & $\underset{* \star * \star}{0.081}$ & $\underset{* * \star}{0.111}$ & -0.010 & 1 & \\
\hline $\mathbf{R Q}$ & -0.011 & 0.006 & $\underset{* * *}{0.036}$ & -0.043 & $\underset{* \star * \star}{0.041}$ & -0.019 & -0.076 & $\underset{\star \star \star}{0.2697}$ & $\begin{array}{c}0.024 \\
*\end{array}$ & $\underset{* \star \star}{0.168}$ & $\underset{\star \star \star \star}{0.085}$ & $\underset{* \star *}{0.515}$ & 1 \\
\hline
\end{tabular}

Note. Source: the authors. ALTM = Altman Z-score according to Zang (2012); REP = lagged overall WMAC score; ROA = net income before extraordinary items divided by total assets; LEV = total debts divided by total assets; INT = market value divided by shareholders' equity; EPS = natural logarithm of earnings per share; SIZE = natural logarithm of total assets; IFRS = dummy in which 1 represents years following the adoption of IFRS, 0 otherwise; AUD = dummy variable in which 1 represents firm audited by one of the Big Four, 0 otherwise; CRIS = dummy variable in which 1 represents year 2008, 0 otherwise; GDP = annual variation in GDP; $\mathrm{RL}=$ rule of law; $\mathrm{RQ}=$ regulatory quality.

${ }^{* * *}=$ significant at $1 \% ;{ }^{* *}=$ significant at $5 \% ;{ }^{*}=$ significant at $10 \%$.

As expected, ALTM and REP were positively correlated $(p<0.01)$. Note that high ALTM values indicate low bankruptcy risk; thus, a positive association between ALTM and REP means that companies with good reputation are at low risk of bankruptcy. Up to this point in the analysis, the study hypothesis cannot be rejected, supporting the notion that, generally, firms with good reputation and which honor their debts acquire long-lasting legitimacy in the eyes of stakeholders and are unlikely to go bankrupt.

INT, EPS, and ROA were positively related to ALTM; thus, the greater these variables were, the smaller the bankruptcy risk. On the other hand, LEV and SIZE were negatively related to ALTM; thus, the greater the leverage and the size of the firm, the greater the bankruptcy risk. CRIS was also negatively correlated with ALTM, meaning that at the height of the financial crisis (2008) the sampled firms were at greater risk of bankruptcy. Moreover, variation in GDP was negatively correlated with ALTM. In other words, the greater the variation in GDP, the smaller the risk of bankruptcy; or, put simply, the higher the GDP, the stronger the financial health of local firms.

The observed effect of the control variables (ROA, LEV, INT, EPS, SIZE) on REP (Table 5) confirms the literature and the results of our descriptive analysis. It should be pointed out that the WMAC ranking includes only large firms (Fombrun, Gardberg, \& Sever, 2000). The fact that our sample was limited to large firms may have had an impact on the variable REP (proxied by the overall WMAC score), especially since company size has been shown to be positively correlated with reputation (Fombrun \& Shanley, 1990). 
We submitted our findings to panel data multiple linear regression analysis with fixed effects and robust errors to evaluate the relationship between corporate reputation and bankruptcy risk. Table 6 shows the results of the model, with ALTM as dependent variable. Because ALTM is an inverse parameter (greater values indicate lower risk), a positive correlation with REP was expected.

Table 6

Results of the multiple linear regression analysis

\begin{tabular}{|c|c|c|c|c|c|c|}
\hline \multirow{2}{*}{ Variable } & \multicolumn{2}{|c|}{ Descriptives } & \multirow{2}{*}{$\begin{array}{c}\text { Sample_1 } \\
\text { Coeff. }\end{array}$} & \multirow{2}{*}{$\begin{array}{c}\text { Sample_2 } \\
\text { Coeff. }\end{array}$} & \multirow{2}{*}{$\begin{array}{c}\text { Sample_3 } \\
\text { Coeff. }\end{array}$} & \multirow{2}{*}{ VIF } \\
\hline & Mean & Std. dev. & & & & \\
\hline REP & 3.30 & 3.2438 & $0.0035^{\star *}$ & $0.0006^{\star *}$ & $0.0037^{\star}$ & 1.00 \\
\hline $\mathrm{ROA}$ & 0.1079 & 0.0805 & $2.4134^{\star * *}$ & $2.4401^{\star \star \star}$ & $2.5664^{* * *}$ & 1.66 \\
\hline LEV & 0.6218 & 0.2043 & $-1.4014^{* * *}$ & $-1.4015^{\star \star *}$ & $-1.4479^{* * *}$ & 1.53 \\
\hline INT & 1.3542 & 0.6812 & $0.1961^{* * *}$ & $0.1906^{* * *}$ & $0.2348^{* * *}$ & 1.65 \\
\hline EPS & 2.7297 & 2.8755 & $0.0095^{\star * *}$ & $0.0346^{\star *}$ & $0.0024^{*}$ & 1.10 \\
\hline SIZE & 23.4274 & 1.9831 & $-0.0679^{\star * *}$ & $-0.0703^{* * *}$ & $-0.0587^{* * *}$ & 1.46 \\
\hline IFRS & 0.3843 & 0.2789 & 0.0005 & 0.0119 & 0.0566 & 1.24 \\
\hline AUD & 0.9815 & 0.1347 & $0.1426^{* * *}$ & $0.0995^{\star *}$ & $0.4975^{\star \star \star}$ & 1.11 \\
\hline CRIS & 0.0767 & 0.2661 & $0.0515^{* * *}$ & $0.0522^{* * *}$ & 0.0132 & 1.18 \\
\hline GDP & 1.7724 & 1.6663 & -0.0007 & -0.0012 & -0.0022 & 1.16 \\
\hline $\mathrm{RL}$ & 1.6090 & 0.083 & $0.1429^{\star *}$ & $0.0961^{* *}$ & $0.4349^{* * *}$ & 1.38 \\
\hline $\mathrm{RQ}$ & 1.4502 & 0.1565 & $0.0956^{* * *}$ & $0.9258^{* *}$ & $0.0148^{*}$ & 1.39 \\
\hline \multirow[t]{6}{*}{ Constant } & - & - & $-0.9083^{* * *}$ & $-0.9257^{* * *}$ & $-0.6710^{* *}$ & - \\
\hline & $\mathrm{F}$ & & $1103.03^{* \star *}$ & $882.62^{\star \star \star}$ & 126.89 & \\
\hline & Within & & 0.7505 & 0.7501 & 0.7603 & \\
\hline & Between & & 0.8631 & 0.6533 & 0.7143 & \\
\hline & Overall & & 0.7509 & 0.7497 & 0.7596 & \\
\hline & $\mathrm{N}$ & & 4.578 & 4.413 & 165 & \\
\hline
\end{tabular}

Note. Source: the authors. Sample_1 = total sample; Sample_2 = subsample of US firms only; Sample_3 = subsample of nonUS firms. ALTM = Altman Z-score according to Zang (2012); REP = lagged overall WMAC score; ROA = net income before extraordinary items divided by total assets; LEV = total debts divided by total assets; INT = market value divided by shareholders' equity; EPS = natural logarithm of earnings per share; SIZE = natural logarithm of total assets; IFRS = dummy variable in which 1 represents years following the adoption of IFRS, 0 otherwise; AUD = dummy variable in which 1 represents firm audited by one of the Big Four, 0 otherwise; CRIS = dummy variable in which 1 represents the year 2008, 0 otherwise; GDP = annual variation in $\mathrm{GDP} ; \mathrm{RL}=$ rule of law; $\mathrm{RQ}=$ regulatory quality.

${ }^{* \star *}=$ significant at $1 \% ;{ }^{* *}=$ significant at $5 \% ;{ }^{*}=$ significant at $10 \%$.

Initially, it should be noted that the statistical model was significant at $1 \%$ in the $F$ test, indicating that the independent variable or one of the control variables influenced the dependent variable.

As shown in Table 6, reputation was significantly correlated with risk at the level of $1 \%$. The positive correlation between REP and ALTM was expected: firms with good reputation tend to honor their debts and are less likely to become insolvent (Casado et al., 2017; Krueger \& Wrolstad, 2016). 
As a reflection of the quality of the firm's conduct in the eyes of the stakeholders, corporate reputation is a valuable asset that takes a long time to build. To preserve their reputation, firms strive to meet stakeholders' expectations, even when the market slows down, and this makes them more vulnerable to market fluctuations (Delgado-García et al., 2013). The finding by Delgado-García et al. (2013) of an inverse association between corporate reputation and nonsystematic risk in a sample of Spanish firms, contrasting with the results of the present study, may be explained by considerable differences in context. In fact, many aspects of the relationship between risk and reputation remain to be clarified.

The WMAC ranking quantifies reputation on a scale from 0 to 10 (the higher, the more reputable). The mean REP value of the sample was low (Table 3) but, as explained in the Methodology section, REP was assigned the value 0 in the years a firm was absent from the ranking.

Despite the finding of negative operating performance in some of the sampled firms, the mean operating performance was positive, possibly due to good reputation, considering that our sample consisted of firms included in the Forbes ranking for one or more years during the study period (2005-2016). This finding is supported by the literature on corporate reputation, which shows good reputation to be associated with superior performance (Fombrun \& Shanley, 1990; Roberts \& Dowling, 2002).

On the average, LEV was $\sim 62 \%$ in our sample, indicating that over three fifths of the capital structure was represented by third-party capital. In addition, the finding of a strongly negative association $(p<0.01)$ between LEV and ALTM shows that the smaller the indebtedness of a firm, the greater its ability to pay debts.

The level of intangibility (a proxy for market performance) was high in the sample, as shown by the fact that market value was equivalent to or greater than equity. As with ROA, this may be due to good reputation, as suggested by Fombrun and Van Riel (1997) and Van Riel and Fombrun (2007).

The variable earnings per share (EPS) may be used as an indicator of the attractiveness of an organization (Nassirzadeh, Saei, Salehi, \& Varnosfaderani, 2013). Thus, the greater the EPS, the more attractive the firm. With an EPS value (without the natural logarithm) above 0 , the sampled firms would be considered attractive, as suggested by the literature on reputation (Fombrun \& Van Riel, 1997; Van Riel \& Fombrun, 2007). As observed in Table 6, the variable EPS and the ALTM Z-score were positively and significantly $(p<0.01)$ associated, indicating that the greater the attractiveness of the firm, the smaller the risk of bankruptcy.

As an indicator of a firm's attractiveness (Nassirzadeh et al., 2013), EPS is akin to the concept of corporate reputation. A firm which enjoys the trust of investors is likely to be more attractive and, consequently, more efficient at capturing resources, thereby reducing the risk of bankruptcy (Srivastava \& Gnyawali, 2011). 
Almost all the sampled firms (98.15\%) were audited by one of the Big Four, and audit quality was positively associated with bankruptcy risk. Matching the results of Butler and Fauver (2006) and Godlewski (2006), in our study regulatory quality (RQ) and rule of law (RL) yielded positive and significant coefficients, suggesting that the government's ability to promote the development of the private sector and trust in the government's good-will and respect for property rights have a positive influence on corporate financial health, reducing the risk of insolvency.

Table 6 is an analysis of robustness using two subsamples, one consisting of US firms only (Sample_2) and one with non-US firms (Sample_3). The results remained unchanged.

In addition, we conducted an analysis on a subsample of firms with REP $\neq 0$, the results of which are displayed in Table 7.

Table 7

Results of the multiple linear regression analysis

\begin{tabular}{|c|c|c|c|c|c|c|}
\hline \multirow{2}{*}{ Variable } & \multicolumn{2}{|c|}{ Descriptives } & \multirow{2}{*}{$\begin{array}{c}\text { Sample_1 } \\
\text { Coeff. }\end{array}$} & \multirow{2}{*}{$\begin{array}{c}\text { Sample_2 } \\
\text { Coeff. }\end{array}$} & \multirow{2}{*}{$\begin{array}{c}\text { Sample_3 } \\
\text { Coeff. }\end{array}$} & \multirow{2}{*}{ VIF } \\
\hline & Mean & Std. dev. & & & & \\
\hline REP_WOUT & 6.3697 & 0.8677 & $0.0372^{\star \star \star}$ & $0.0099^{* *}$ & $0.0216^{*}$ & 1.04 \\
\hline $\mathrm{ROA}$ & 0.1078 & 0.0722 & $2.1759^{\star \star \star}$ & $2.7016^{\star * \star}$ & $2.9223^{\star * *}$ & 1.88 \\
\hline LEV & 0.6223 & 0.2002 & $-1.3903^{* * *}$ & $-1.4017^{* * *}$ & $-1.4968^{* * *}$ & 1.50 \\
\hline INT & 1.3427 & 0.6492 & $0.2243^{* * *}$ & $0.1778^{* * *}$ & $0.2111^{* * *}$ & 1.81 \\
\hline EPS & 2.7249 & 2.9266 & $0.0097^{* * *}$ & $0.0378^{* *}$ & $0.0033^{*}$ & 1.10 \\
\hline SIZE & 23.3912 & 1.9123 & $0.0690^{* * *}$ & $0.0686^{* * *}$ & $0.0587^{* * *}$ & 1.42 \\
\hline IFRS & 0.1056 & 0.3024 & 0.0014 & $0.0447^{*}$ & $0.0873^{*}$ & 1.47 \\
\hline AUD & 0.9819 & 1.1332 & $0.1318^{* * *}$ & $0.1211^{* *}$ & 0.1841 & 1.12 \\
\hline CRIS & 0.0785 & 0.2690 & $0.0638^{* *}$ & $0.0716^{* *}$ & 0.0088 & 1.18 \\
\hline GDP & 1.7648 & 1.7239 & 0.0054 & 0.0004 & 0.0079 & 1.15 \\
\hline $\mathrm{RL}$ & 1.6104 & 0.0786 & 0.1244 & 0.0565 & 0.3948 & 1.37 \\
\hline $\mathrm{RQ}$ & 1.4510 & 0.1545 & $0.1647^{\star \star *}$ & $0.2151^{* *}$ & $0.1491^{*}$ & 1.38 \\
\hline Constant & - & - & $-1.2311^{* * *}$ & $-0.8163^{* *}$ & $-0.6164^{*}$ & \\
\hline \multicolumn{3}{|c|}{$\mathrm{F}$} & $515.34^{* \star *}$ & $495.07^{\star * *}$ & $81.48^{\star \star *}$ & \\
\hline \multicolumn{3}{|c|}{ Within } & 0.7316 & 0.7607 & 0.8069 & \\
\hline \multicolumn{3}{|c|}{ Between } & 0.7932 & 0.8721 & 0.8485 & \\
\hline \multicolumn{3}{|c|}{ Overall } & 0.7318 & 0.7614 & 0.8075 & \\
\hline \multicolumn{3}{|c|}{$N$} & 2.391 & 2.286 & 105 & \\
\hline
\end{tabular}

Note. Source: the authors. Sample_1 = total sample; Sample_2 = subsample of US firms only; Sample_3 = subsample of nonUS firms. ALTM = Altman Z-score according to Zang (2012); REP WOUT = lagged overall WMAC score $(R E P \neq 0) ; R O A=$ net income before extraordinary items divided by total assets; LEV = total debts divided by total assets; INT = market value divided by shareholders' equity; EPS = natural logarithm of earnings per share; SIZE = natural logarithm of total assets; IFRS = dummy variable in which 1 represents years following the adoption of IFRS, 0 otherwise; AUD = dummy variable in which 1 represents firm audited by one of the Big Four, 0 otherwise; CRIS = dummy variable in which 1 represents year 2008, 0 otherwise; GDP = annual variation in GDP; $R L=$ rule of law; $R Q=$ regulatory quality.

${ }^{* \star *}=$ significant at $1 \% ;{ }^{* *}=$ significant at $5 \% ;{ }^{*}=$ significant at $10 \%$. 
In the subsample of firms with REP $\neq 0$, the mean REP value was 6.37 . The association between REP and ALTM remained significant and positive, confirming that reputation is positively reflected in financial health. This is an indication that firms paying their debts have a better reputation on the market. Thus, the result was the same whether corporate reputation was represented by the variable REP (firms assigned the value 0 in the years of absence from the ranking) or the variable REP_WOUT (firms excluded from the analysis in the years of absence from the ranking). We also exclude non-US firms (not tabulated), and we note that the result has remained constant.

We conducted additional tests (Table 7) on the subsample of US firms (Sample_2) and the subsample of non-US firms (Sample_3). Again, the results remained unchanged.

In short, the study hypothesis (corporate reputation is negatively correlated with bankruptcy risk) could not be rejected, suggesting that corporate reputation may be used as an information signal by investors in the quest for a balance between risk and return in specific ventures.

\section{Conclusion}

The purpose of this study was to evaluate the relationship between corporate reputation and bankruptcy risk in public firms. To do so, we submitted data from 441 firms to multiple linear regression analysis with fixed effects and robust errors. We used bankruptcy risk (expressed as Altman Z-score) as dependent variable and corporate reputation (proxied by the overall WMAC score) was used as independent variable.

The multiple linear regression analysis showed that corporate reputation has a negative effect on bankruptcy risk. Hence $H_{1}$ could not be rejected, a finding supported by Casado, Yanez, and Peláez (2017), who also found reputation to be associated with lower bankruptcy risk, and by Gregory (1998) and Jones, Jones, and Little (2000), who concluded that corporate reputation helps protect the firm against market slowdowns, but not by Delgado-García et al. (2013), who found a positive association between corporate reputation and systematic risk, perhaps due to the differences between the two types of risk. Thus, based on our sample, firms with high reputation are indeed less prone to bankruptcy.

Good corporate reputation generates a number of benefits through competitive advantage, as posited by Resource-Based View. For example, it increases the firm's market value and its attractiveness to stakeholders and potential partners, especially investors, and makes it possible to raise prices. This is compatible with the adoption of good practices of corporate governance.

By evaluating the relationship between reputation and risk, our analysis is relevant in both the academic and the entrepreneurial setting. The importance of risk management should also be pointed out: when firms attract and strive to secure the favor of stakeholders, they increase risk for the same reason. However, as shown by our results, this effect is counterbalanced by good

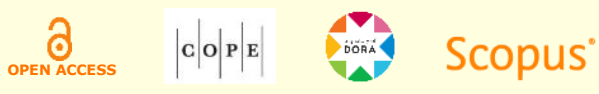


reputation. In addition, our study shows that, in view of its negative association with bankruptcy risk, reputation is an essential strategic resource to attain longevity on the market and overcome crises. Academically speaking, our study expands current knowledge of corporate risk by directly probing the little-explored relationship between corporate risk and reputation, in that it presents evidence that the higher the company's reputation, the less likely to become insolvent; or, put simply, the higher the corporate reputation, the greater the likelihood that the company will honor its debts.

The limitation of the sample to firms on the WMAC ranking may have introduced a bias with regard to company size. In addition, the ranking features mainly US firms and so displays an uneven distribution of countries. Another potential limitation is the use of reputation as independent variable. Reputation is a poorly defined construct without a universally accepted metric. Unsurprisingly, the use of reputation rankings is still common practice, especially in archival research.

Our findings point to corporate reputation as a promising field of study. For example, future investigations might explore the relationship between reputational risk and corporate reputation or the relationship between business risk disclosure and corporate reputation, since well-reputed firms tend to disclose more information on risks, generating greater credibility in the eyes of stakeholders. Finally, we suggest evaluating the relationship between bankruptcy risk and corporate reputation in a comprehensive sample of firms from emerging markets.

\section{References}

Ahn, S., \& Choi, W. (2009). The role of bank monitoring in corporate governance: Evidence from borrowers' earnings management behavior. Journal of Banking $\mathcal{E}$ Finance, 33(2), 425-434. https://doi.org/10.1016/j.jbankfin.2008.08.013

Altman, E. I. (1968). Financial ratios, discriminant analysis and the prediction of corporate bankruptcy. The Journal of Finance, 23(4), 589-609. https://doi.org/10.1111/j.1540-6261.1968.tb00843.x

Altman, E. I., Iwanicz-Drozdowska, M., Laitinen, E. K., \& Suvas, A. (2017). Financial distress prediction in an international context: A review and empirical analysis of Altman's Z-score model. Journal of International Financial Management $\mathcal{E}$ Accounting, 28(2), 131-171. https://doi.org/10.1111/jifm.12053

Barnett, M. L., Jermier, J. M., \& Lafferty, B. A. (2006). Corporate reputation: The definitional landscape. Corporate Reputation Review, 9(1), 26-38. https://doi.org/10.1057/palgrave.crr.1550012

Barney, J. (1991). Firm resources and sustained competitive advantage. Journal of Management, 17(1), 99-120. https://doi.org/10.1177/014920639101700108

Beaver, W. H. (1966). Financial ratios as predictors of failure. Journal of Accounting Research, 4, 71-111. https://doi.org/10.2307/2490171

Berens, G., \& Van Riel, C. B. M. (2004). Corporate associations in the academic literature: Three main streams of thought in the reputation measurement literature. Corporate Reputation Review, 7(2), 161-178. https://doi.org/10.1057/palgrave.crr.1540218

Borghesi, R., Houston, J. F., \& Naranjo, A. (2014). Corporate socially responsible investments: CEO altruism, reputation, and shareholder interests. Journal of Corporate Finance, 26, 164-181. https://doi.org/10.1016/j.jcorpfin.2014.03.008 
Brammer, S., Millington, A., \& Pavelin, S. (2009). Corporate reputation and women on the board. British Journal of Management, 20(1), 17-29. https://doi.org/10.1111/j.1467-8551.2008.00600.x

Butler, A. W., \& Fauver, L. (2006). Institutional environment and sovereign credit ratings. Financial Management, 35(3), 53-79. https://doi.org/10.1111/j.1755-053x.2006.tb00147.x

Casado, A. M., Yánez, E. R., \& Peláez, A. (2017). The value of corporate reputation in the bankruptcy risk. Journal of Systemics, Cybernetics and Informatics, 15(1), 38-43. Retrieved from http://www.iiisci.org/Journal/SCI/FullText.asp?var=\&id=SA332RV16

Castro, M. G., \& López, N. J. E. (2006). La importancia de la reputación empresarial en la obtención de ventajas competitivas sostenibles. Investigaciones Europeas de Dirección y Economía de la Empresa, 12(3), 29-39.

Chan, A. L.-C., Hsu, A. W.-H., \& Lee, E. (2013). Does mandatory IFRS adoption affect the credit ratings of foreign firms cross-listed in the U.S.? Accounting Horizons, 27(3), 491-510. https://doi.org/10.2308/acch-50483

Chava, S., \& Jarrow, R. A. (2004). Bankruptcy prediction with industry effects. Review of Finance, 8(4), 537-569. https://doi.org/10.1093/rof/8.4.537

Chun, R. (2005). Corporate reputation: Meaning and measurement. International Journal of Management Reviews, 7(2), 91-109. https://doi.org/10.1111/j.1468-2370.2005.00109.x

Cole, S. (2012). The impact of reputation on market value. World Economics, 13(3), 47-68. Retrieved from https://www.world-economicsjournal.com/Journal/Papers/The\%20Impact\%20of\%20Reputation\%20on\%20Market\%20Value.details?ID=526

Delgado-García, J. B., Quevedo-Puente, E., \& Díez-Esteban, J. M. (2013). The impact of corporate reputation on firm risk: A panel data analysis of Spanish quoted firms. British Journal of Management, 24(1), 1-20. https://doi.org/10.1111/j.1467-8551.2011.00782.x

Eiser, J. R., Bostrom, A., Burton, I., Johnston, D. M., McClure, J., Paton, D., Pligt, J. van der, \& White, M. P. (2012). Risk interpretation and action: A conceptual framework for responses to natural hazards. International Journal of Disaster Risk Reduction, 1, 5-16. https://doi.org/10.1016/j.ijdrr.2012.05.002

Feldman, P. M., Bahamonde, R. A., \& Bellido, I. V. (2014). A new approach for measuring corporate reputation. Revista de Administração de Empresas, 54(1), 53-66. http://dx.doi.org/10.1590/S0034-759020140106

Flanagan, D. J., \& O'Shaughnessy, K. C. (2005). The effect of layoffs on firm reputation. Journal of Management, 31(3), 445-463. https://doi.org/10.1177/0149206304272186

Fombrun, C. J. (2007). List of lists: A compilation of international corporate reputation ratings. Corporate Reputation Review, 10(2), 144-153. https://doi.org/10.1057/palgrave.crr.1550047

Fombrun, C. J., Gardberg, N. A., \& Barnett, M. L. (2000). Opportunity platforms and safety nets: Corporate citizenship and reputational risk. Business and Society Review, 105(1), 85-106. https://doi.org/10.1111/00453609.00066

Fombrun, C. J., Gardberg, N. A., \& Sever, J. M. (2000). The reputation QuotientSM: A multi-stakeholder measure of corporate reputation. Journal of Brand Management, 7(4), 241-255. https://doi.org/10.1057/bm.2000.10

Fombrun, C., \& Shanley, M. (1990). What's in a name? Reputation building and corporate strategy. Academy of Management Journal, 33(2), 233-258. https://doi.org/10.5465/256324

Fombrun, C., \& Van Riel, C. B. M. (1997). The reputational landscape. Corporate Reputation Review, 1(1/2), 5-13. https://doi.org/10.1057/palgrave.crr.1540008

Godlewski, C. J. (2006). Regulatory and institutional determinants of credit risk taking and a bank's default in emerging market economies: A two-step approach. Journal of Emerging Market Finance, 5(2), 183-206. https://doi.org/10.1177/097265270600500204

Gotsi, M., \& Wilson, A. M. (2001). Corporate reputation: Seeking a definition. Corporate Communications: An International Journal, 6(1), 24-30. https://doi.org/10.1108/13563280110381189

Gregory, J. R. (1998). Does corporate reputation provide a cushion to companies facing market volatility? Some supportive evidence. Corporate Reputation Review, 1(3), 288-290. https://doi.org/10.1057/palgrave.crr.1540050

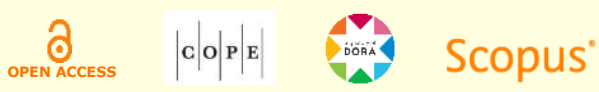


Gupta, A. (2014). Risk management and simulation. New York, NY: CRC Press.

Hammond, S. A., \& Slocum, J. W., Junior. (1996). The impact of prior firm financial performance on subsequent corporate reputation. Journal of Business Ethics, 15(2), 159-165. https://doi.org/10.1007/bf00705584

Hasseldine, J., Salama, A. I., \& Toms, J. S. (2005). Quantity versus quality: The impact of environmental disclosures on the reputations of UK Plcs. The British Accounting Review, 37(2), 231-248. https://doi.org/10.1016/j.bar.2004.10.003

Henkel, J. (2009). The risk-return paradox for strategic management: Disentangling true and spurious effects. Strategic Management Journal, 30(3), 287-303. https://doi.org/10.1002/smj.734

Herremans, I. M., Akathaporn, P., \& McInnes, M. (1993). An investigation of corporate social responsibility reputation and economic performance. Accounting, Organizations and Society, 18(7/8), 587-604. https://doi.org/10.1016/0361-3682(93)90044-7

Himme, A., \& Fischer, M. (2014). Drivers of the cost of capital: The joint role of non-financial metrics. International Journal of Research in Marketing, 31(2), 224-238. https://doi.org/10.1016/j.ijresmar.2013.10.006

Horrigan, J. O. (1966). The determinants of long-term credit standing with financial ratios. Journal of Accounting Research, 4, 44-62. https://doi.org/10.2307/2490168

Hull, J. C. (2015). Risk management and financial institution (4th. ed.). New Jersey, NJ: John Wiley \& Sons.

Inglis, R., Morley, C., \& Sammut, P. (2006). Corporate reputation and organizational performance: An Australian study. Managerial Auditing Journal, 21(9), 934-947. https://doi.org/10.1108/02686900610705028

Jiraporn, P., Jiraporn, N., Boeprasert, A., \& Chang, K. (2014). Does corporate social responsibility (CSR) improve credit ratings? Evidence from geographic identification. Financial Management, 43(3), 505-531. https://doi.org/10.1111/fima.12044

Jones, G. H., Jones, B. H., \& Little, P. (2000). Reputation as reservoir: Buffering against loss in times of economic crisis. Corporate Reputation Review, 3(1), 21-29. https://doi.org/10.1057/palgrave.crr.1540096

Krueger, T. M., \& Wrolstad, M. A. (2016). Impact of the reputation Quotient ${ }^{\circledR}$ on investment performance. Corporate Reputation Review, 19(2), 140-151. https://doi.org/10.1057/crr.2016.5

Linsley, P. M., \& Shrives, P. J. (2006). Risk reporting: A study of risk disclosures in the annual reports of UK companies. The British Accounting Review, 38(4), 387-404. https://doi.org/10.1016/j.bar.2006.05.002

$\mathrm{Li}, \mathrm{S}$. (2010). Does mandatory adoption of international financial reporting standards in the European Union reduce the cost of equity capital? The Accounting Review, 85(2), 607-636. https://doi.org/10.2308/accr.2010.85.2.607

Melo, T., \& Garrido-Morgado, A. (2012). Corporate reputation: A combination of social responsibility and industry. Corporate Social Responsibility and Environmental Management, 19(1), 11-31. https://doi.org/10.1002/csr.260

Musteen, M., Datta, D. K., \& Kemmerer, B. (2010). Corporate reputation: Do board characteristics matter? British Journal of Management, 21(2), 498-510. https://doi.org/10.1111/j.1467-8551.2009.00676.x

Musteen, M., Rhyne L., \& Zheng, C. (2013). Asset or constraint: Corporate reputation and MNCs' involvement in the least developed countries. Journal of World Business, 48(3), 321-328. https://doi.org/10.1016/j.jwb.2012.07.016

Nassirzadeh, F., Saei, M. J., Salehi, M., \& Varnosfaderani, F. R. (2013). CEO's reputation: Corporate performance. SCMS Journal of Indian Management, 10(3), 5-12. Retrieved from https://www.scms.edu.in/journal/article?journal_id=23

Roberts, P. W., \& Dowling, G. R. (2002). Corporate reputation and sustained superior financial performance. Strategic Management Journal, 23(12), 1077-1093. https://doi.org/10.1002/smj.274

Rodríguez-Moreno, M., \& Peña, J. I. (2013). Systemic risk measures: The simpler the better? Journal of Banking $\mathcal{E}$ Finance, 37(6), 1817-1831. https://doi.org/10.1016/j.jbankfin.2012.07.010 
Srivastava, M. K., \& Gnyawali, D. R. (2011). When do relational resources matter? Leveraging portfolio technological resources for breakthrough innovation. Academy of Management Journal, 54(4), 797-810. https://doi.org/10.5465/amj.2011.64870140

Tinoco, M. H., \& Wilson, N. (2013). Financial distress and bankruptcy prediction among listed companies using accounting, market and macroeconomic variables. International Review of Financial Analysis, 30, 394-419. https://doi.org/10.1016/j.irfa.2013.02.013

Toms, J. S. (2002). Firm resources, quality signals and the determinants of corporate environmental reputation: Some UK evidence. The British Accounting Review, 34(3), 257-282. https://doi.org/10.1006/bare.2002.0211

Van Riel, C. B., \& Fombrun, C. J. (2007). Essentials of corporate communication: Implementing practices for effective reputation management. New York, NY: Routledge.

Walker, K. (2010). A systematic review of the corporate reputation literature: Definition, measurement, and theory. Corporate Reputation Review, 12(4), 357-387. https://doi.org/10.1057/crr.2009.26

Wartick, S. L. (2002). Measuring corporate reputation - Definition and data. Business E Society, 41(4), $371-392$. https://doi.org/10.1177/0007650302238774

Zang, A. Y. (2012). Evidence on the trade-off between real activities manipulation and accrual-based earnings management. The Accounting Review, 87(2), 675-703. https://doi.org/10.2308/accr-10196

\section{Author contributions}

$1^{\text {st }}$ author: conceptualization (equal), data curation (equal), formal analysis (equal), investigation (equal), methodology (lead), project administration (equal), resources (equal), software (equal), supervision (equal), validation (equal), visualization (equal), writing-original draft (equal), writing-review and editing (supporting).

$2^{\text {nd }}$ author: conceptualization (equal), data curation (equal), formal analysis (equal), investigation (equal), methodology (supporting), project administration (equal), resources (equal), software (equal), supervision (equal), validation (equal), visualization (equal), writing-original draft (equal), writing-review and editing (lead).

$3^{\text {rd }}$ author: conceptualization (equal), data curation (equal), formal analysis (equal), investigation (equal), methodology (supporting), project administration (equal), resources (equal), software (equal), supervision (equal), validation (equal), visualization (equal), writing-original draft (equal), writing-review and editing (supporting).

$4^{\text {th }}$ author: conceptualization (equal), data curation (equal), formal analysis (equal), investigation (equal), methodology (supporting), project administration (supporting), resources (equal), software (equal), supervision (equal), validation (equal), visualization (equal), writing-original draft (equal), writing-review and editing (supporting).

\section{Authors}

\section{Alan Diógenes Góis (in memoriam)}

Universidade de São Paulo, Departamento de Contabilidade e Atuária

Av. Prof. Luciano Gualberto, 908, 05508-010, São Paulo, SP, Brazil

alandgois@hotmail.com

(iD) https://orcid.org/0000-0003-3534-6557

\section{Márcia Martins Mendes De Luca}

Universidade Federal do Ceará, Faculdade de Economia, Administração, Atuária e Contabilidade

Av. da Universidade, 2486, Benfica, 60020-180, Fortaleza, CE, Brazil

marciadeluca@ufc.br

D https://orcid.org/0000-0002-9995-5637

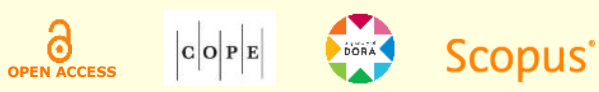


Gerlando Augusto Sampaio Franco de Lima

University of Illinois at Urbana-Champaign, Gies College of Business

104 Wohlers Hall, 1206 South Sixth Street, Champaign, IL, 61820, USA

gerlando@illinois.edu

(iD) https://orcid.org/0000-0002-2414-2543

\section{Jislene Trindade Medeiros}

Universidade Federal do Ceará, Faculdade de Economia, Administração, Atuária e Contabilidade Av. da Universidade, 2486, Benfica, 60020-180, Fortaleza, CE, Brazil jislenetm@gmail.com

(iD) https://orcid.org/0000-0003-0941-0228

Peer review is responsible for acknowledging an article's potential contribution to the frontiers of scholarly knowledge on business or public administration. The authors are the ultimate responsible for the consistency of the theoretical references, the accurate report of empirical data, the personal perspectives, and the use of copyrighted material. 